\title{
Agricultura familiar
}

A agricultura familiar é constituída por pequenas unidades produtivas rurais, em que os agricultores podem ser tanto proprietários da terra e dos meios de trabalho como parceiros ou meeiros, dependendo da região, mas a mão de obra e a gestão das atividades são familiares. A maior parte da produção destina-se à subsistência da família e apenas o excedente é comercializado. Em determinadas épocas do ano, quando possuem tempo livre, esses agricultores também podem realizar trabalho fora da unidade familiar, buscando complementar a renda da família. A agricultura familiar possui sua própria lógica interna de desenvolvimento.

Além disso, as unidades produtivas familiares caracterizam-se por uma autonomia relativa em face aos mercados em que comercializam parte de sua produção, embora mantenham relações estruturais com o sistema econômico dominante do qual fazem parte. Historicamente a agricultura familiar construiu uma lógica interna de desenvolvimento própria, uma vez que se destina fundamentalmente a produzir valores de uso, para o próprio consumo, e só comercializa a produção excedente, mas, à medida que se estreitam suas relações com os mercados, essa lógica vai sofrendo transformações e se subordinando progressivamente à lógica do capitalismo industrial em que está inserida, mesmo que de forma parcial e indireta. Esse processo se intensifica, no Brasil, sobretudo a partir da segunda metade do século XX, com a modernização da agricultura empresarial. Por isso, a agricultura familiar costuma ser vista não apenas como uma forma particular de produção, mas também como um modo de vida, ainda que ocupando uma posição subordinada, tanto econômica como politicamente, diante de uma sociedade preponderantemente urbana, em que se insere cada vez mais.

Por tais características e pelo papel especial que desempenha no sistema capitalista, a agricultura familiar constituiu-se, ao longo da história, em objeto de um intenso debate, entre visões teóricas diferentes sobre a posição especial que ocupa na evolução e no contexto 
do desenvolvimento econômico de um país. A tradição marxista, baseada fundamentalmente nas posições de Lênin e Kautsky, apontava para a tendência ao desaparecimento gradual da agricultura familiar no curso do desenvolvimento capitalista, pois, num sistema capitalista, que se caracteriza pela separação entre os proprietários dos meios de produção e os trabalhadores diretos, o agricultor familiar figura como algo "anacrônico", uma vez que o próprio agricultor permanece, ao mesmo tempo, como proprietário da terra e dos meios de produção e como trabalhador direto na produção agrícola. Nesse sentido, a agricultura familiar, em si mesma, não se caracteriza como uma organização econômica capitalista, pois não emprega mão de obra assalariada e os trabalhadores diretos continuam sendo proprietários da terra e dos meios de produção.

Assim, de acordo com a perspectiva teórica desses autores, a lógica do desenvolvimento capitalista deveria transformar os agricultores familiares em duas novas categorias típicas do modo de produção capitalista: os agricultores mais fortes, e em melhores condições econômicas, seriam transformados em futuros capitalistas agrícolas e os pequenos seriam transformados em operários agrícolas. No entanto, esta previsão teórica só foi confirmada parcialmente pela história posterior do capitalismo, pois, mesmo nos países mais desenvolvidos, a agricultura familiar, além de não ter desaparecido, foi capaz, ainda, de reestruturar-se, para sobreviver e poder reproduzir-se, e, inclusive, em muitos casos, tornou-se um segmento importante na produção de alimentos para o mercado capitalista.

Outros autores, no entanto, ressaltam que a permanência da agricultura familiar, no contexto da economia capitalista, se deve as suas próprias especificidades e a sua natureza de produção simples de mercadorias, que a habilitam a articular-se, de diferentes maneiras, com a produção capitalista. Em muitos casos, a produção familiar pode, inclusive, tornar-se funcional para a produção capitalista, na medida em que produz alimentos mais baratos para os trabalhadores assalariados, agrícolas ou urbanos, contribuindo para o barateamento dos custos de produção, bem como de alimentos mais saudáveis. Análises desse tipo parecem trazer uma grande contribuição para o entendimento da 
agricultura familiar, ao colocá-la dentro do sistema capitalista, explicitando suas diversas formas de articulação, e não pensá-la à margem ou em oposição ao modo de produção capitalista.

No Oeste catarinense, a peculiar articulação da agricultura familiar com a indústria frigorífica representa um caso particularmente relevante, no contexto teórico mencionado. Ou seja, a relevância da agricultura familiar persiste e se desenvolve, tanto em nível de Brasil como regional. No Brasil, dados do IBGE indicam que, em 2009, dos 5.175.000 estabelecimentos agrícolas do país, 84,4\% eram familiares, ocupavam $24,3 \%$ da área cultivada total, representavam $74,4 \%$ das pessoas ocupadas e eram responsáveis por 38\% do Valor Bruto da Produção agrícola.

Apesar dessa importância, ao menos numérica, que a agricultura familiar representa, o seu debate, no Brasil,é relativamente recente, mas ganhou força a partir do final dos anos 1980 e início dos anos 1990, quando a organização dos pequenos produtores familiares e os movimentos sociais levaram a discussão para o âmbito acadêmico e político, procurando discutir sobre o espaço e o papel dos pequenos produtores rurais no desenvolvimento da agricultura nacional.

Nas décadas de 1970 e 1980, as políticas públicas do Estado brasileiro praticamente ignoraram a questão dos pequenos agricultores, pois a orientação política pretendia apoiar o processo conhecido como "modernização conservadora" da agricultura, embora houvesse toda uma discussão sobre a funcionalidade da agricultura para o desenvolvimento urbano industrial do país. De fato, a legitimação da agricultura familiar perante o Estado só veio a ocorrer em meados dos anos 1990, especialmente com os dados do Censo Agropecuário de 1996. A criação de uma política específica para este segmento da agricultura brasileira, o Programa Nacional de Fortalecimento da Agricultura Familiar (PRONAF), representa uma forma de legitimação da agricultura familiar no Brasil, como já vinha sendo feito na maioria dos países desenvolvidos.

Essa discussão mostrou, entre outras coisas, que além de não ter ocorrido a anunciada decomposição do campesinato brasileiro, como se apregoava, a agricultura familiar, enquanto forma social de 
produção, ainda ocupa um lugar importante no cenário atual da economia e da sociedade brasileiras.

No Oeste catarinense, a agricultura familiar assume características próprias. A estrutura agrária é formada de pequenas áreas, onde cerca de $95 \%$ das propriedades têm menos de 50 hectares e 70 $\%$ delas têm menos de 20 hectares. Cerca de $50 \%$ da população economicamente ativa da região trabalha em atividades agropecuárias. O desenvolvimento da agricultura familiar, nesta região, desde muito cedo, esteve atrelado ao desenvolvimento da agroindústria frigorífica.

\section{REFERÊNCIAS}

COLETTI, Tomé; LINS, Hoyêdo Nunes.A suinocultura no vértice das relações entre agroindústria e agricultura familiar no Oeste de Santa Catarina. Porto Alegre: Ensaios FEE, v. 32, n. 2, p. 339-360, nov. 2011. MIOR, Luiz Carlos. Agricultores familiares, agroindústrias e redes de desenvolvimento rural. Chapecó: Argos, 2005.

NIEDERLE, Sidnei Luiz; KOCK EXTERKOTER, Rudinei. Formação e Desenvolvimento da Agricultura Familiar no Oeste Catarinense: buscando novos caminhos. XXI Encontro Nacional de Geografia Agrária. Uberlândia, 2012.

PLEIN, Clério. A Formação da Agricultura Familiar no Oeste de Santa Catarina: o caso das colônias Porto Feliz e Porto Novo. Revista Faz

Ciência, Unioeste, Cascavel, vol. 07, n. 01, 2005, p. 79-102. 